\title{
Implementation of Gamification in The Hotel Membership System for Repurchase
}

\author{
Toni Anwar ${ }^{1, *, a}$, Anugerah Bagus Wijaya ${ }^{1, b}$, Cayadewi Paramita ${ }^{1}$, Muhamad Zidan Fathoni ${ }^{1}$ \\ ${ }^{1}$ Faculty of Computer Science, AMIKOM University Purwokerto, J1. Letjend Pol. Soemarto No.126, Watumas, Purwanegara, \\ Kec. Purwokerto Utara, Kabupaten Banyumas, Jawa Tengah 53127 \\ *,a toni@ amikompurwokerto.ac.id (Corresponding Author), ${ }^{\mathrm{b}}$ anugerah@amikompurwokerto.ac.id
}

\begin{abstract}
Javaheritage Hotel is a 4-star hotel located in the tourist city of Purwokerto. Java Heritage already has a membership system to increase consumers' purchases back to the hotel. The current membership system allows consumers to purchase members who will get an active stay voucher for one year. Javaheritage requires increasing the number of repurchases by member and non-member consumers to Javaheritage hotels. Gamification applies scoring points, competition, and game rules to other activities or activities. This study aims to design a hotel membership system that implements gamification to increase repurchase at java heritage hotels. The output of this research is a research journal, and the TKT that will be achieved is at level 7. Namely, the Demonstration of a prototype system in a natural environment. The development method used is RAD (Rapid Application Development) and system design depiction using UML.
\end{abstract}

Keywords-Gamification, UML, RAD, Membership, System

\section{Introduction}

Banyumas Regency is a tourist city in Central Java [1]. There are many hotels in Purwokerto City, one of which is the Java Heritage Hotel. Hotel Javaheritage is a 4-star hotel located in the tourist city of Purwokerto. Hotel Javaheritage consistently innovates to win the competition. Hotel Java Heritage has a membership system that aims to increase consumers will make purchases back to the hotel [2] [3]. The current membership system is that consumers are offered members who will get an active stay voucher for one year. Javaheritage increases the number of repurchases by member and non-member consumers to hotels. Gamification applies the elements in a game (game), such as scoring points, competition, and rules, into other activities or activities. Gamification can increase engagement because some challenges and goals must be achieved by obtaining scores [4]. Gamification also increases learning motivation for students who use LMS and MOOC [5], [6]. It is necessary to implement gamification in the Hotel membership system from this background.

\section{Research Methodology}

\section{A. Method}

This research methodology uses the RAD (Rapid Application Development) system development method [7] to create a Prototype Hotel Membership System with gamification implementation. RAD has three stages in system development: 1) Requirements Planning Phase by identifying objectives and identifying requirements from these objectives. 2) Design Workshop to design and improve, described as a workshop. 3) Implementation / Implementation Phase The analyzer works with the users intensely during the workshop and designs the business and non-technical aspects of the company.

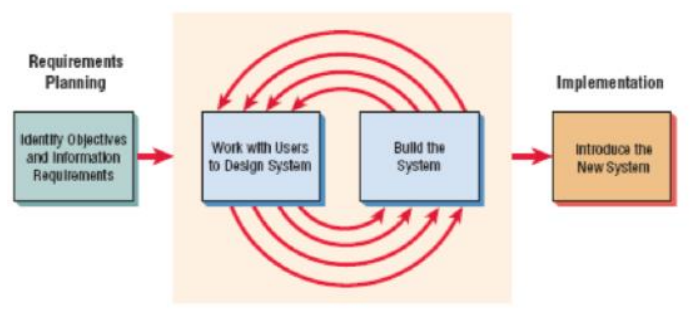

Figure 1. RAD system development method [7] 


\section{Results and Discussion}

These research results are a membership hotel design with gamification to get consumers to repurchase. The stages in making a gamification hotel membership system are analyzed.

\section{A. Requirements Planning}

The application requirement planning is taken from the membership system requirement data from the hotel, namely in the form of user profiles, points earned from each purchase, and products that are usually purchased. While the gamification side that will be implemented are:

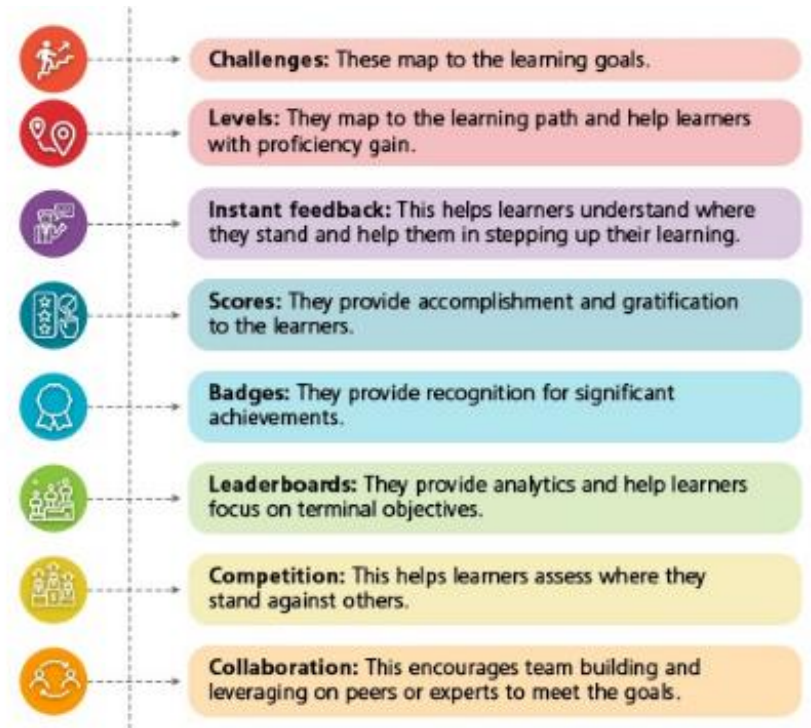

Figure 2 Gamification elements [8]

From the gamification reference implemented in the e-learning system. There are challenges, instant feedback levels, scores, hedges, leaderboard competition and collaboration to increase children's learning motivation in e-learning. The gamification elements that will be implemented in the membership system are Challenges, Levels, Badges, Leaderboards, Competition and Collaboration.

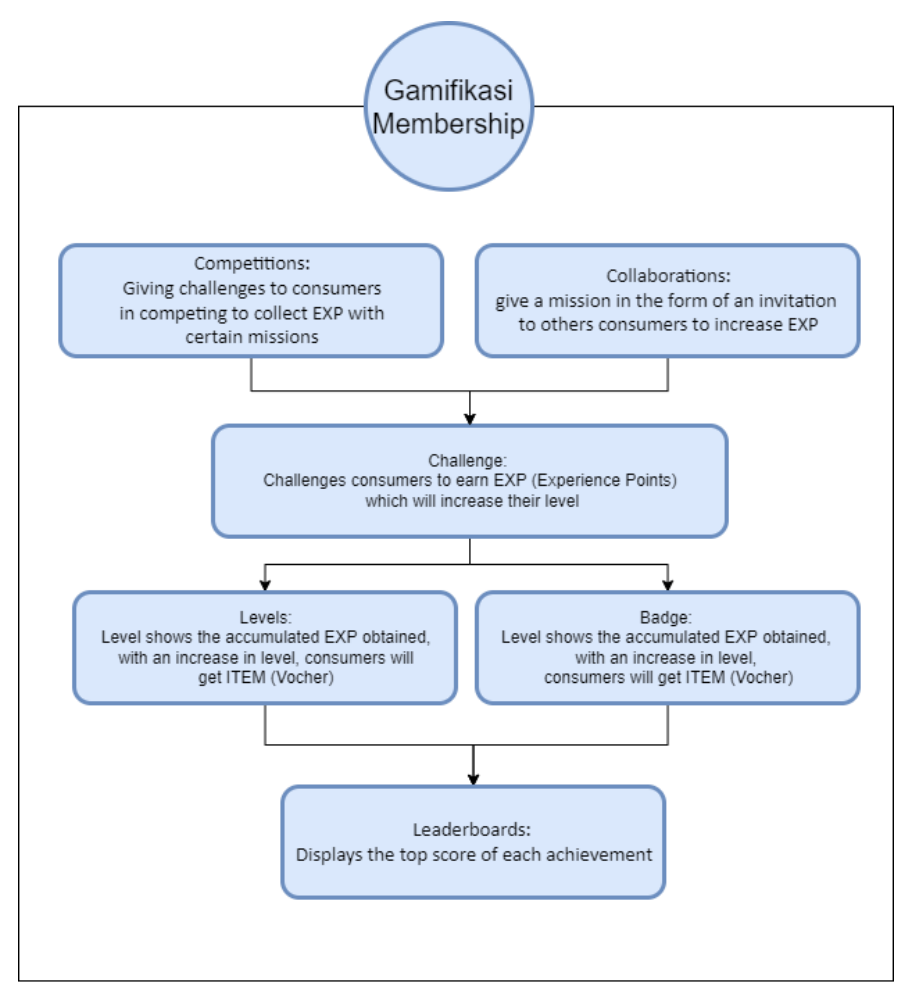

Figure 3 Elements of gamification in the membership system

The flow of membership gamification in this study relies on EXP (experience points), which increases levels and earns badges; EXP is obtained by competing and collaboration between consumers who are always expected to remember and make repurchases. All achievements will be displayed on the leader board to increase the competitiveness of each customer.

\section{B. Design Workshop}

This stage allows researchers to design a prototype membership gamification. The design stages use the Unified Modeling Language (UML) [9]. The UML designs that will be implemented in the design of the hotel membership system are Use Cases, Activity diagrams, Sequence diagrams and classes. The following diagram illustrates the UML membership gamification. 


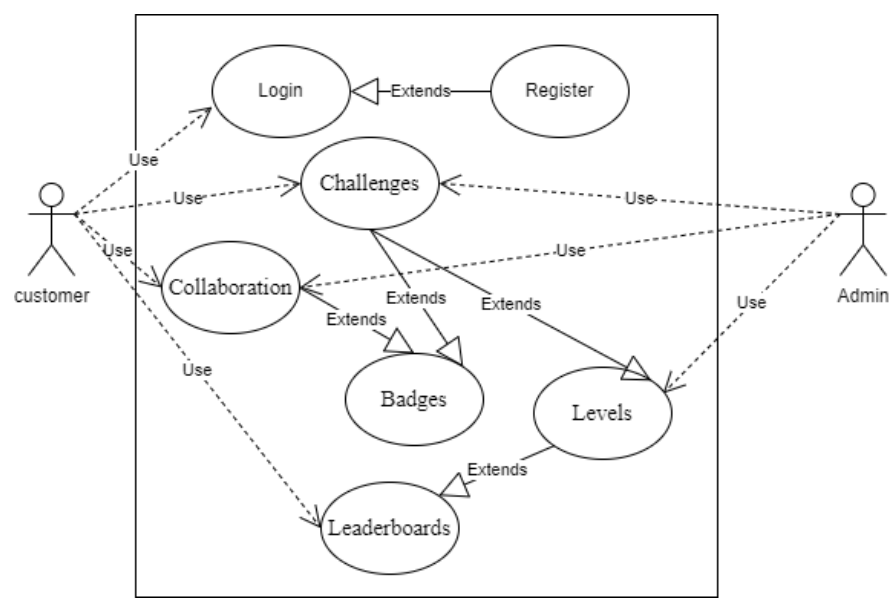

Figure 4. Usecase Membership Gamification

The use case diagram depicts two actors, namely consumers and admins. Consumers interact with the system via login; if not, they will be directed to the registration process. Consumers can also access challenges and collaboration to get EXP. Every EXP they get from the mission will be accumulated to get badges. And level up. Each EXP will be accumulated and displayed on the leaderboards under a pseudonym every month.

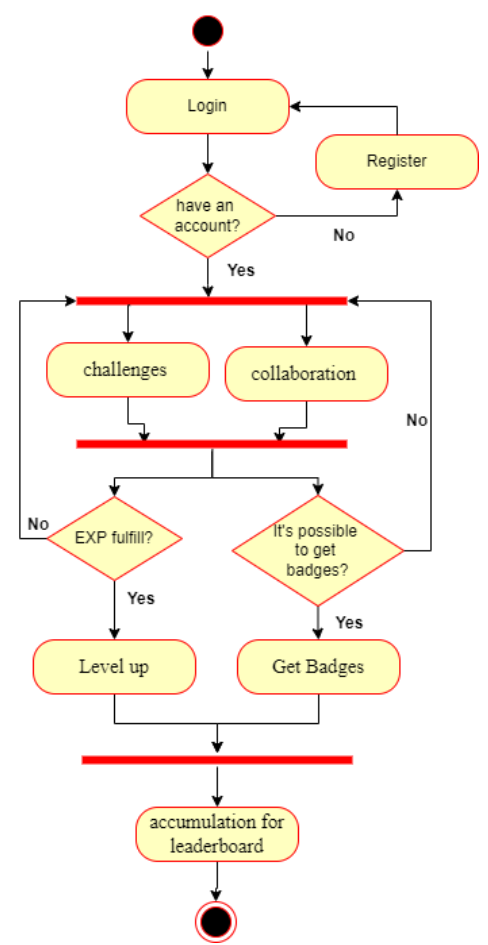

Figure 5. Activity diagram Membership Gamification
The activity diagram in Figure 4 clearly explains how consumers are directed to continue to do missions (purchase products) after leveling up or getting badges. Consumers will be given rewards in product discount vouchers, and what they have achieved, they will buyback. With the leaderboard, consumers will compete to get the highest score.

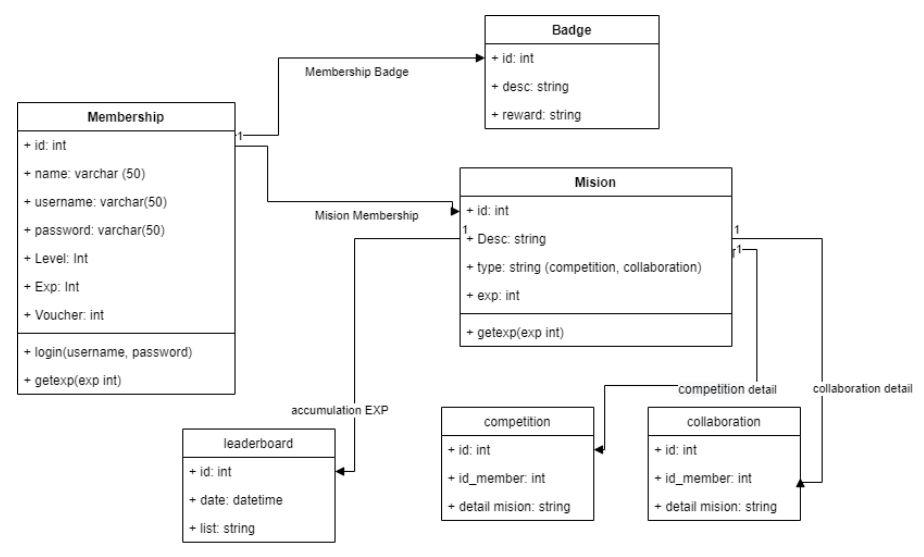

Figure 6. Class diagram Membership Gamification

The hotel gamification membership divides the classes needed to develop the prototype in the class diagram. Competition and collaboration classes are shown to users in one form, namely mission classes, level attributes and also exp attached to members so that members directly feel all benefits obtained from leveling up.

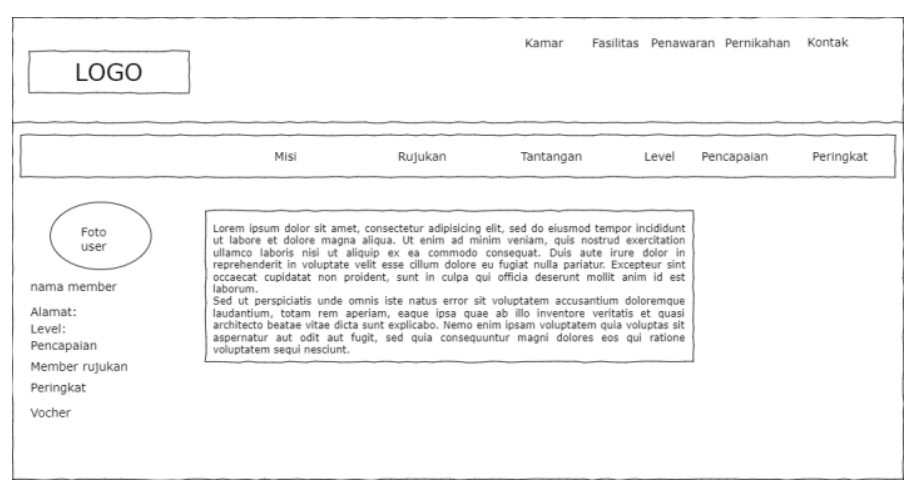

Figure 7. Gamification membership interface design

The interface design that is made is displayed in one view by partitioning it with pagination. The mission menu, referrals, level challenges, and achievements become an easy display menu for consumers to use. Most of the systems in gamification are run on the 
backend so that the running of the application in the eyes of members is not too confusing.

\section{Implementation}

The implementation phase is to apply all the designs that have been compiled and form a prototype. The prototype made will later go through the black box testing stage to test the prototype'[10]. The prototype is displayed in the form of a print screen by displaying the 3 main features of the gamification membership system.

1) leaderboard page

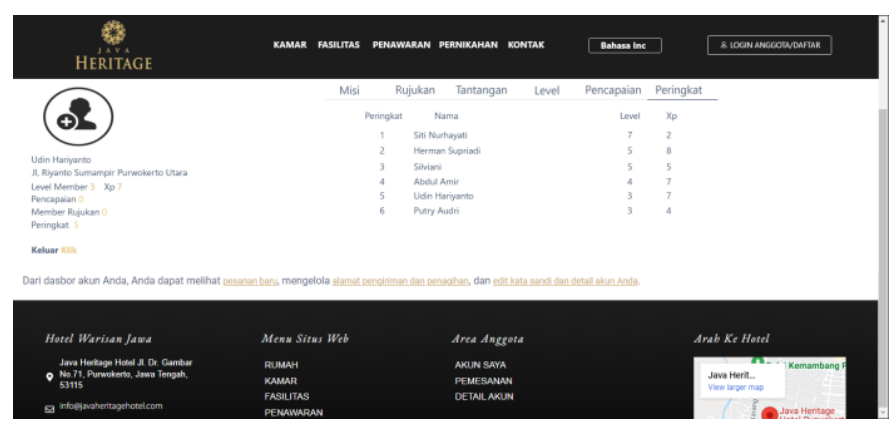

Figure 8. Leader board

2) Badge page

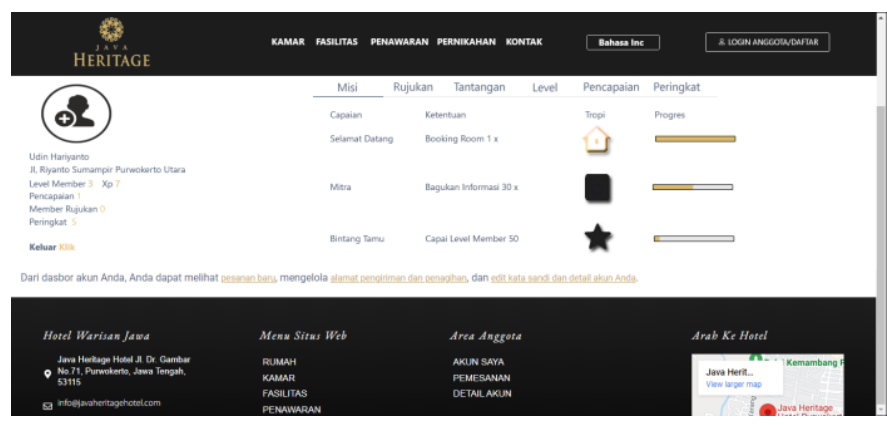

Figure 9. Badge

3) Mission page

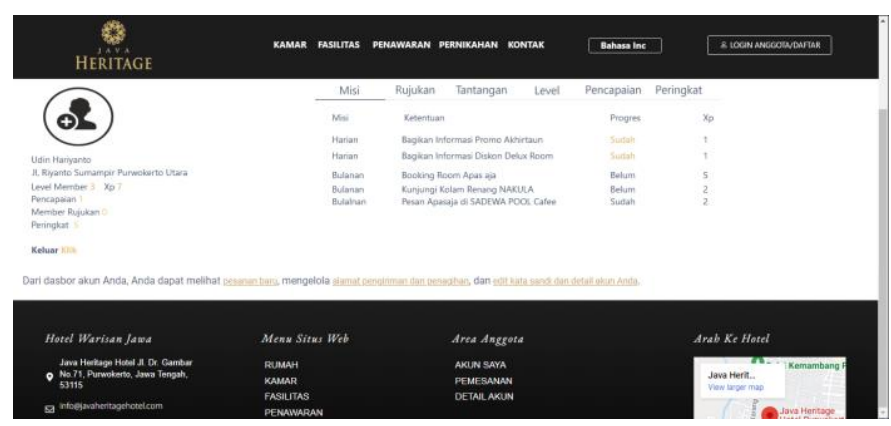

Figure 10. mission
Table 1 testing black box prototype [10].

\begin{tabular}{|c|c|c|c|c|}
\hline No & Use case test & Pre-condition & Test & Result \\
\hline 1 & User login & $\begin{array}{c}\text { the username } \\
\text { and password } \\
\text { fields are } \\
\text { empty }\end{array}$ & $\begin{array}{c}\text { Entering } \\
\text { correct and } \\
\text { incorrect } \\
\text { usernames }\end{array}$ & Succeed \\
\hline 2 & Gain EXP & $\begin{array}{c}\text { Members } \\
\text { complete } \\
\text { missions } \\
\text { (collaboration } \\
\text { or } \\
\text { competition) }\end{array}$ & $\begin{array}{c}\text { Member } \\
\text { completed the } \\
\text { mission }\end{array}$ & succeed \\
\hline 3 & Level up & $\begin{array}{c}\text { Members } \\
\text { almost meet } \\
\text { EXP to level } \\
\text { up }\end{array}$ & $\begin{array}{l}\text { Members } \\
\text { complete } \\
\text { missions }\end{array}$ & succeed \\
\hline 4 & Earn badges & $\begin{array}{c}\text { Members } \\
\text { complete } \\
\text { missions with } \\
\text { badge rewards }\end{array}$ & $\begin{array}{l}\text { Member } \\
\text { completed the } \\
\text { mission }\end{array}$ & succeed \\
\hline 5 & $\begin{array}{c}\text { Update } \\
\text { Leaderboard }\end{array}$ & $\begin{array}{l}\text { The members } \\
\text { have gone } \\
\text { through the } \\
\text { process to get } \\
\text { EXP }\end{array}$ & $\begin{array}{l}\text { The system } \\
\text { works to } \\
\text { record data for } \\
\text { ranking }\end{array}$ & succeed \\
\hline
\end{tabular}

\section{Conclusion}

This study concludes that a prototype membership hotel is made by gamification to make consumers buy back the product from the research object. Tests were carried out using a black box with the results of the prototype run according to its functionality. Suggestions for further research are to test consumers' responses to the gamification membership system systematically.

\section{Acknowledgment}

The author would like to thank you to the University of Amikom Purwokerto, which has supported morally and materially implementing this research. Thank you also to all parties involved from the object of research and respondents. 


\section{References}

[1] N. Marlina, "Kemandirian masyarakat desa wisata dalam perspektif community based tourism: Studi kasus Desa Ketengger, Kabupaten Banyumas", (The independence of the tourism village community in the perspective of community based tourism: A case study of Ketengger Village, Banyumas Regency), Jurnal Ilmiah Ilmu Pemerintahan, Vol. 4, No. 1, p. 17, 2019, doi: 10.14710/jiip.v4i1.4735.

[2] C. M. Hellyana, "Perancangan Sistem Informasi Pemesanan Kamar Hotel (Studi Kasus: Hotel Java Heritage Purwoketo)", (Hotel Room Reservation Information System Design (Case Study: Hotel Java Heritage Purwoketo), IJSE - Indonesian Journal on Software Engineering Perancangan, Vol. 3, No. 1, pp. 50-57, 2017.

[3] S. Tanford, C. Raab, and Y. S. Kim, "The influence of reward program membership and commitment on hotel loyalty," Journal of Hospitality and Tourism Research, Vol. 35, No. 3, pp. 279-307, 2011, DOI: $10.1177 / 1096348010382236$.

[4] A. Pratomo, "Pengaruh Konsep Gamifikasi Terhadap Tingkat Engagement", (Effect of Gamification Concept on Engagement Level), THE Journal : Tourism and Hospitality Essentials Journal, Vol. 8, No. 2, p. 63, 2018, doi: 10.17509/thej.v8i2.13740.
[5] P. A. Sunarya, U. Rahardja, Q. Aini, and A. Khoirunisa, "Implementasi Gamification Sebagai Manajemen Pendidikan Untuk Motivasi Pembelajaran", (Implementation of Gamification as Educational Management for Learning Motivation), Edutech, Vol. 18, No. 1, p. 79, 2019, doi: 10.17509/e.v18i1.14697.

[6] R. E. Saputro, S. Salam, M. H. Zakaria, and T. Anwar, "A gamification framework to enhance students' intrinsic motivation on MOOC," Telkomnika (Telecommunication Computing Electronics and Control), Vol. 17, No. 1, pp. 170-178, 2019, DOI: 10.12928/TELKOMNIKA.v17i1.10090.

[7] K. Kenneth E and K. Julie E, Systems Analysis And Design, 8th ed. New Jersey: Prentice-Hall.

[8] Binus University, "Tren dan Tips Gamifikasi untuk Pembelajaran Online", (Gamification Trends and Tips for Online Learning), Sep. 11, 2019.

[9] S. Al-Fedaghi, "Model Multiplicity (UML) Versus Model Singularity in System Requirements and Design", 2021.

[10] A. A. Ilham, A. Azmi, A. R. Ramadhani, D. F. Abeda Falah, and A. Saifudin, "Pengujian Sistem Informasi Parkir PT KISP Berbasis Desktop dengan Metode Black-Box", (Pengujian Sistem Informasi Parkir PT KISP Berbasis Desktop dengan Metode Black-Box), Jurnal Informatika Universitas Pamulang, Vol. 6, No. 1, p. 96, Mar. 2021, doi: 10.32493/informatika.v6i1.8547. 